\title{
Pseudomonas osteomyelitis following puncture wounds
}

\author{
A. E. MACKINNON \\ M.B., B.S., F.R.C.S. \\ The Western Infirmary, Glasgow
}

\begin{abstract}
Summary
Puncture wounds of the foot are rarely followed by serious complications but in 1968 Johanson reported eleven cases of osteomyelitis, the infecting organism being Pseudomonas aeruginosa in each instance. He described the typical features of these infections which were confirmed by Minnefor, Olsen and Carver (1971) and Hagler (1971).

This paper records a further case of Pseudomonas osteomyelitis and the previously recorded cases are reviewed. Attention is drawn to the importance of surgical as well as antibiotic treatment of these infections.
\end{abstract}

\section{Patient D.T.}

An 11-year-old boy attended hospital having sustained a puncture wound beneath the metatarsophalangeal joint of the right big toe caused by stepping on a rusty nail that day. He was treated with injections of Triplopen* and tetanus toxoid, and a magnesium sulphate dressing was applied to the wound. Initially there was some improvement but after 8 days the joint became more inflamed, painful and swollen. X-ray at this time time showed no changes. A course of ampicillin and cloxacillin was started and bed rest at home was ordered. No improvement was made so he was admitted on the eleventh day after the accident for further investigation while continuing the same treatment. His temperature was normal, ESR $48 \mathrm{~mm}$ in first hour, WCC 7400. X-ray showed destruction of the proximal phalanx. As there was no sign of improvement, drainage was undertaken 11 days later when serous fluid with some thick pus was released from the joint. There was destruction of the head of the metatarsal and the base of the proximal phalanx both of which were thoroughly curetted and the wound left to drain freely. Culture of the pus grew only $\boldsymbol{P}$. aeruginosa sensitive to gentamicin which was

* Triplopen injection contains in each vial: benethamine penicillin G $475 \mathrm{mg}$; procaine penicillin $250 \mathrm{mg}$; sodium penicillin G $300 \mathrm{mg}$.

Present address: Senior Surgical Registrar, The Royal Manchester Children's Hospital, Pendlebury, Manchester. therefore given for 5 days. Following this, the signs of inflammation settled rapidly and he was discharged 11 days later ( 33 days after the accident) with the wound completely healed. When seen 6 days later the only signs were some pain on pressure over the metatarso-phalangeal joint and slight swelling. The boy then failed to attend for follow-up but was traced at home some 14 months later. He was found to be symptom free and able to join in all sporting activities.

\section{Discussion}

Johanson (1968) and Minnefor et al. (1971) have described the typical history of Pseudomonas osteomyelitis following puncture wounds of the foot. The patient is usually a child who steps on a nail or similar object, commonly injuring the region of the first metatarso-phalangeal joint, though other weight-bearing areas of the foot may be involved. At hospital, the treament given is superficial toilet, tetanus prophylaxis and an antibiotic chiefly effective against Gram-positive organisms. After initial improvement lasting a few days there is increasing local pain, swelling and joint effusion if a joint is involved. It is probable that the early improvement is due to control of Gram-positive organisms allowing the growth of $\boldsymbol{P}$. aeruginosa, which is able to produce penicillinase. This relapse is not associated with systemic upset. In most cases the antibiotic has then been changed but without response, and eventually surgical exploration is undertaken when turbid fluid is released with a small amount of pus. The cartilage covering the bone is found to be necrotic and Johanson (1968) considers this to be a typical feature. Hitherto most patients have been given prolonged treatment with antibiotics and immobilization, and although the infection is eventually eradicated there are usually permanent X-ray changes indicating joint damage.

Table 1 summarizes the cases described by other authors, together with the present case. Johanson (1968) gives details of only one of his patients but all were treated with immobilization and antibiotics for some months. The report of Fegin et al. (1970) 
TABLE 1. Summary of reported cases of Pseudomonas osteomyelitis following puncture wound

\begin{tabular}{|c|c|c|c|c|c|c|}
\hline Author & Age & Site of injury & Instrument & Initial antibiotic & $\begin{array}{l}\text { Delay to } \\
\text { surgery }\end{array}$ & Further antibiotic \\
\hline \multirow[t]{2}{*}{$\begin{array}{c}\text { Johanson, eleven } \\
\text { cases (nine not } \\
\text { described) }\end{array}$} & 12 & $\begin{array}{l}4 / 5 \text { tarsometa- } \\
\text { tarsal joint }\end{array}$ & Nail & $\begin{array}{l}\text { Penicillin/oxytetra- } \\
\text { cycline/triacetyl- } \\
\text { oleandomycin. } \\
\text { Penicillin G/ methi- } \\
\text { cillin/streptomycin }\end{array}$ & 34 days & Colistimethate \\
\hline & - & Second toe & - & - & - & - \\
\hline \multirow[t]{3}{*}{$\begin{array}{l}\text { Minnefor et al., } \\
\text { three cases }\end{array}$} & 7 & Left big toe & Rusty nail & $\begin{array}{l}\text { Unstated. } \\
\text { Penicillin/strepto- } \\
\text { mycin }\end{array}$ & $\begin{array}{l}9 \text { days, second } \\
\text { operation } \\
16 \text { days }\end{array}$ & Colistin \\
\hline & 7 & Right big toe & Nail & 'Broad spectrum' & $\begin{array}{l}4 \text { days, } \\
2 \text { further } \\
\text { operations }\end{array}$ & $\begin{array}{l}\text { Colistin, developed } \\
\text { renal failure, } \\
\text { eventual recovery }\end{array}$ \\
\hline & 7 & $\begin{array}{l}\text { Right } 4 / 5 \text { meta- } \\
\text { tarsophalangeal } \\
\text { jo:nt }\end{array}$ & $\begin{array}{l}\text { Axle of toy } \\
\text { car }\end{array}$ & $\begin{array}{l}\text { Penicillin/cloxacillin/ } \\
\text { ampicillin }\end{array}$ & $\begin{array}{l}28 \text { days, } \\
\text { second } \\
\text { operation } \\
14 \text { days }\end{array}$ & $\begin{array}{l}\text { Gentamicin and } \\
\text { carbenicillin }\end{array}$ \\
\hline $\begin{array}{l}\text { Fegin et al., } \\
\text { one case }\end{array}$ & 10 & Right calcaneum & Nail & $\begin{array}{l}\text { Tetracycline. Strepto- } \\
\text { mycin/penicillin. }\end{array}$ & - & 一 \\
\hline Hagler, one case & 8 & $\begin{array}{l}\text { Left second meta- } \\
\text { tarsophalangeal } \\
\text { joint }\end{array}$ & Nail & $\begin{array}{l}\text { Ampicillin/oxacillin/ } \\
\text { penicillin. Cloxa- } \\
\text { cillin }\end{array}$ & $\begin{array}{l}7 \text { days, second } \\
\text { operation } \\
28 \text { days }\end{array}$ & $\begin{array}{l}\text { Gentamicin and } \\
\text { penicillin } 2 \text { weeks. } \\
\text { Colistimethate } \\
2 \text { weeks }\end{array}$ \\
\hline Present report & 11 & $\begin{array}{l}\text { Metatarsophalan- } \\
\text { geal joint, right } \\
\text { big toe }\end{array}$ & Rusty nail & $\begin{array}{l}\text { Penicillin. Ampicillin/ } \\
\text { cloxacillin }\end{array}$ & 22 days & $\begin{array}{l}\text { Gentamicin for } \\
5 \text { days }\end{array}$ \\
\hline
\end{tabular}

is taken from a review of osteomyelitis of the calcaneum and also is lacking in detail. The case reported in the present paper closely follows the pattern described by Johanson (1968).

The prompt treatment of this condition depends on awareness of the fact that when infection following a puncture wound does not respond to the antibiotic administered the causative organism may be $P$. aeruginosa. All the antibiotics effective against this organism must be given parenterally, and the hazards of prolonged therapy as pointed out by Minnefor et al. (1971) underline the need to recognize the value of early surgery in this type of infection. The evidence presented here suggests that prolonged chemotherapy is not required provided the surgical clearance of infected tissue is thorough.

\section{Acknowledgment}

The author wishes to thank Mr G. A. Whitefield, Consultant Orthopaedic Surgeon at the Southern General Hospital, Glasgow, for permission to report this case, and for his help in preparing the paper.

\section{References}

Fegin, R.D., McAllister, W.H., SAN Joanquin, U.H. \& MiddleKAMP, J.N. (1970) Osteomyelitis of the calcaneus. American Journal of Diseases of Children, 119, 61.

Hagler, D.J. (1971) Pseudomonas osteomyelitis: puncture wounds of the feet. Pediatrics, 48, 672.

Johanson, P.H. (1968) Pseudomonas infections of the foot following puncture wounds. Journal of the American Medical Association, 204, 262.

Minnefor, A.B., Olsen, M.I. \& Carver, D.H. (1971) Pseudomonas osteomyelitis following puncture wounds of the foot. Pediatrics, 47, 599. 